\title{
Pemetaan Potensi Wilayah Home Industry Di Kecamatan Girimarto Kabupaten Wonogiri
}

\author{
Siskak Akatani Kaudsar ${ }^{1)}$; Sri Hariyati Fitriasih" ${ }^{2)}$; Yustina Retno Wahyu ${ }^{3)}$ \\ 1) ${ }^{3)}$ Program Studi Teknik Informatika, STMIK Sinar Nusantara \\ ${ }^{2)}$ Program Studi Manajemen Informatika, STMIK Sinar Nusantara \\ 1)akatani.kaudsar@gmail.com; ${ }^{2}$ fitri@sinus.ac.id; ${ }^{3)}$ yustina_retno@sinus.ac.id
}

\begin{abstract}
Some residents in Girimarto sub-district make industrial businesses as their main source of livelihood. The lack of information about the home industry in the Girimarto District area results in a less than optimal marketing of industrial products and the sale of products produced only around Wonogiri Regency. In addition, the inequality in the provision of facilities from the government has resulted in the very slow development of home industries. Based on these problems, an application will be made system geographic informality mapping the potential of a home industry in the District of Girimarto to provide information on existing home industries and grouping data using Fuzzy Tahani model. It is database modeling to provide the results of classification of home industry data based on variable number of production per year, number of workers, and the amount of turnover per year. The results of this system classification / grouping of home industry data in accordance with selected criteria with the highest fire strength value 1 from (interval 0-1). This application can help providing information to the public about the home industry in the Girimarto district and be able to classify home industry data so that it can be used as a decision-making material to find ways to develop the industry.
\end{abstract}

Keywords : Geographic Information System, Home Industry, Fuzzy Tahani

\section{PENDAHULUAN}

Kecamatan Girimarto merupakan salah satu kecamatan di Kabupaten Wonogiri yang sebagian penduduknya bergerak dibidang industri. Kurangnya bantuan modal dari pihak pemerintah atau investor lain, kurangnya pelatihan-pelatihan dan pemberian fasilitas dari pemerintah mengakibatkan pertumbuhan industri di Kecamatan Girimarto sangat lambat. Dengan demikian dibutuhkannya peningkatan kemitraan baik dalam pemasaran, teknologi maupun permodalan untuk meningkatkan pertumbuhan industry rumahan yang ada.

Pada sistem pemetaan wilayah ini penulis memilih untuk menggunakan metode Fuzzy Tahani. Fuzzy Tahani merupakan metode fuzzy yang mempergunakan basis data standar. Pada basis data standar, data diklasifikasikan berdasarkan bagaimana data tersebut dipandang oleh user. Oleh karena itu pada basis data standar data yang ditampilkan akan keluar seperti data yang telah disimpan. Tetapi model Tahani ini menggunakan teori himpunan fuzzy pada suatu variabel untuk mendapatkan informasi pada querynya. Sehingga pada pencarian data menggunakan rumus dari derajat keanggotaan pada suatu variabel himpunan fuzzy [1].

Referensi penelitian sebelumnya dengan menggunakan metode Fuzzy Tahani yaitu untuk merekomendasikan pemilihan potensi perumahan [2], mengukur kualitas spring bed dengan menggunakan metode Fuzzy Tahani [3], penentuan rekomendasi sapi potong berkualitas menggunakan Fuzzy Tahani dan C-Means [4],sistem pendukung keputusan perekrutan karyawan tetap [5].

Berdasarkan paparan diatas, yang mendasari penulis membuat sistem informasi geografis pemetaan wilayah yang bertujuan untuk memberikan informasi mengenai klasifikasi atau pengelompokkan data home industry yang ada di Kecamatan Girimarto dengan menggunakan variabel-variabel antara lain jumlah perjualan per tahun, jumlah tenaga kerja, dan jumlah omset atau hasil penjualan per tahun sesuai dengan UU No 20 tahun 2008 tentang Usaha Mikro, Kecil dan Menengah yang diharapkan mampu membantu Dinas terkait dalam pengambilan keputusan sebagai langkah dalam mengembangkan home industry yang ada.

\section{TINJAUAN PUSTAKA}

\subsection{Sistem Informasi Geografis}

Sistem informasi geografis digunakan untuk menyimpan dan memanipulasi informasi geografi. Hal ini memungkinkan data dapat diakses ke suatu lokasi dalam peta yang tersaji secara digital [6].

\subsection{Home Industry}


Home industry adalah semua kegiatan Ekonomi berupa pengolahan barang menjadi bernilai tinggi untuk penggunanya, dilakukan oleh masyarakat pengusaha dari golongan ekonomi lemah atau perusahaan kecil seperti industri rumah tangga dan kerajinan [7].

\subsection{Logika Fuzzy}

Logika fuzzy merupakan generalisasi dari logika klasik (Crip Set) yang hanya memiliki dua nilai keanggotaan yaitu 0 dan 1. Dalam logika fuzzy nilai kebenaran suatu pernyataan bersikap dari sepenuhnya benar samapai dengan sepenuhnya salah [8].

\subsection{Fuzzy Tahani}

Database system adalah suatu sistem informasi yang mengintegrasikan kumpulan data yang saling berhubungan satu dengan lainnya dan membuatnya tersedia untuk beberapa aplikasi dalam suatu organisasi [9].

Fuzzy Tahani adalah salah satu cabang dari logika fuzzy, yang merupakan salah satu metode fuzzy yang menggunakan basis data standar. Tahani mendeskripsikan suatu metode pemrosesan query fuzzy, dengan didasarkan atas manipulasi bahasa yang dikenal dengan nama SQL (Structured Query Language), sehingga model fuzzy Tahani sangat tepat digunakan dalam proses pencarian data yang tepat dan akurat [10].

Langkah-langkah perhitungan metode fuzzy tahani:

1. Menentukan Himpunan Fuzzy

Data atribut yang digunakan masingmasing akan dibagi menjadi 3 himpunan fuzzy yaitu:

a. Variabel Kapasitas Produksi : Sedikit, Sedang, Banyak

b. Variabel Tenaga Kerja : Sedikit, Sedang, Banyak

c. Variabel Omset : Rendah, Sedang, Tinggi

Variabel omset disesuaikan berdasarkan

UU No 20 Tahun 2008 tentang Usaha Mikro, Kecil dan Menengah. Sedangkan variabel tenaga kerja disesuaikan berdasarkan penggolongan perusahaan industri pengolahan menurut Badan Pusat Statistika (BPS).

2. Menggambarkan keanggotaan fuzzy

a. Variabel kapasitas produksi

- Sedikit : $1200-3500 \mathrm{~kg}$

- Sedang : $3000-6000 \mathrm{~kg}$

- Banyak : 5000 - 12000 kg

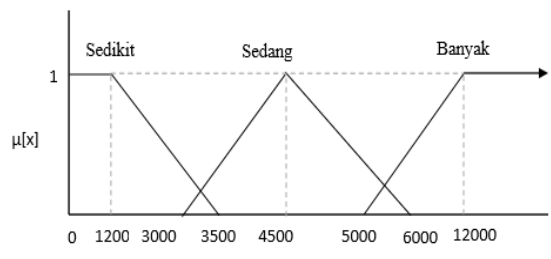

Gambar 1 Kurva Keanggotaan Produksi

b. Variabel tenaga kerja

- Sedikit : 1-4 orang

- Sedang : 5-19 orang

- Banyak : <20 orang

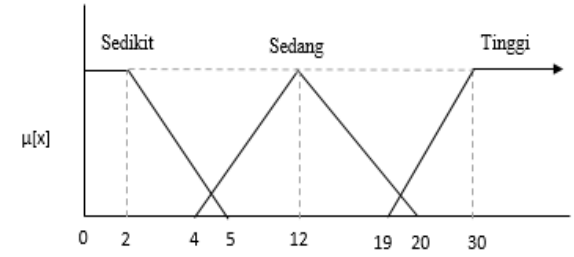

Gambar 2 Kurva Keanggotaan Pekerja

c. Variabel Omset

- Rendah : 0 - 300.000.000

- Sedang : 300.000.000 2.500 .000 .000

- Tinggi : $>2.500 .000 .000$

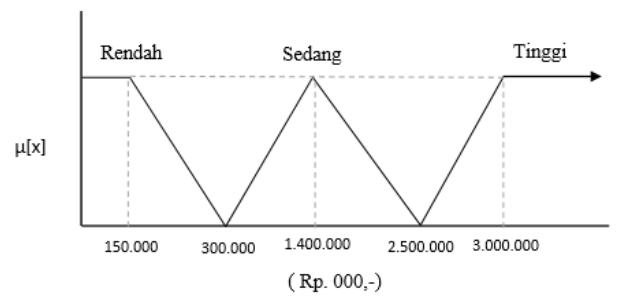

Gambar 3 Kurva keanggotaan omset

3. Fuzzifikasi

Perhitungan fuzzy yaitu pengubahan nilai tegas ke nilai fuzzy.

a. Rumus fuzzifikasi variabel kapasitas produksi

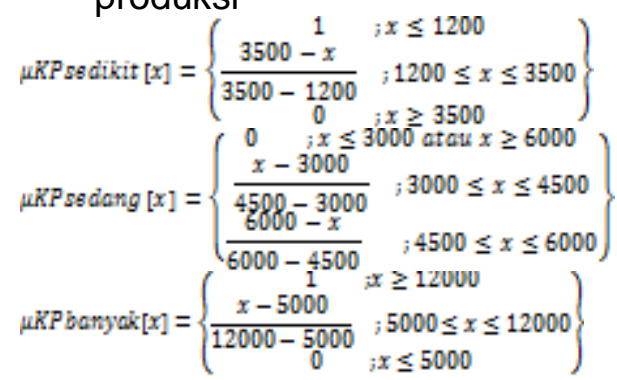

Dimana :

$\mu=$ himpunan

$\mathrm{X}=$ nilai suatu item pada himpunan

b. Rumus fuzzifikasi variabel pekerja 


$$
\begin{aligned}
& \mu \text { TKsedikit }[x]=\left\{\begin{array}{c}
1 ; x \leq 2 \\
5-x ; 2 \leq x<5 \\
5-2 ; x \geq 5
\end{array}\right\} \\
& \mu T \text { Ksedang }[x]=\left\{\begin{array}{c}
0 ; x \leq 4 \text { atar } x \geq 20 \\
\frac{x-4}{12-4} ; 4 \leq x \leq 12 \\
\frac{12-x}{20-12} ; 12 \leq x \leq 20
\end{array}\right\} \\
& \mu \text { TKbanyak }[x]=\left\{\begin{array}{cc}
0 & ; x \leq 19 \\
\frac{x-19}{30-19} ; 19 \leq x \leq 30 \\
1 ; x \geq 30
\end{array}\right\}
\end{aligned}
$$

Dimana :

$\mu=$ himpunan

$\mathrm{X}=$ nilai suatu item pada himpunan

\section{c. Rumus fuzzifikasi variabel omset}

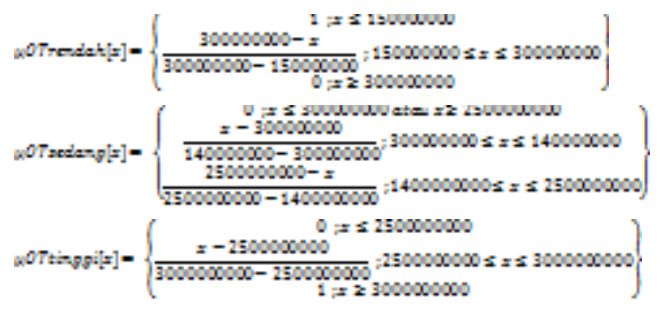

Dimana :

$\mu=$ himpunan

$\mathrm{x}=$ nilai suatu item pada himpunan

4. Defuzifikasi

Mengambil nilai keanggotaan sesuai dengan kriteria yang dipilih, kemudian menggunakan operator AND untuk menghasilkan a-predikat yang diperoleh dengan mengambil nilia keanggotaan terkecil antar elemen pada himpunan-himpunan yang dibuat, dengan persamaan.

$$
\mu_{A \cap B}=\min \left(\mu_{A(x)}, \mu_{B(y)}\right)
$$

\subsection{Kajian Pustaka}

Dhani Eko Setyo Purnomo melakukan penelitian mengenai pemilihan objek wisata di Surakarta menggunakan metode Fuzzy Tahani untuk memberikan kemudahan kepada para pengunjung untuk memilih objek wisata sesuai dengan kriteria harga, fasilitas dan lama berdiri. Implementasi metode fuzzy tahani untuk menganalisa kriteria dan memberikan urutan prioritas objek wisata di Surakarta dengan nilai firestrength antara 0-1 dimana nilai 0 merupakan objek wisata di Surakarta yang tidak direkomendasikan dan nilai 1 merupakan objek wisata di Surakarta yang direkomendasikan [11].
M. Hattan Sururi melakukan penelitian mengenai sistem informasi stok obat dan penjualan obat terlaris pada Apotek RSU Lirboyo Kediri. Tujuan dari penelitian ini untuk melakukan pencatatan keluar masuknya obat serta mampu memberikan peringatan apabila jumlah stok obat sudah mendekati ambang batas minimum. Hasil dari penelitian ini perhitungan stok obat yang ada menggunakan fuzzy tahani, ada beberapa hal yang perlu diperhatikan, diantaranya stok awal obat, jumlah penjualan obat, jumlah pembelian obat, retur penjualan maupun pembelian obat serta tentu saja stok obat yang tersedia sekarang. Hasil dari program ini yaitu mampu memperkirakan berapa jumlah barang yang akan di beli untuk memenuhi jumlah stok di apotek dalam jangka waktu satu bulan berikutnya sehingga jumlah stok akan tetap stabil [12].

Billah Akbar Abdullah melakukan penelitian mengenai sistem informasi geografis UMKM di Kota Cimahi . Tujuan dari penelitian tersebut yaitu untuk memberikan informasi sebaran umkm di Kota Cimahi . Hasil dari penelitian ini yaitu sistem informasi geografis dibangun berbasis webgis dengan menggunakan google maps, sistem dapat menampilkan data-data usaha seperti nama usaha, produk usaha kegiatan usaha, jenis usaha, keterangan usaha, dan alamat usaha [13].

Amelia Fadhila dan Agung Budi Cahyono melakukan penelitian mengenai webgis untuk UMKM di Kota Blitar. Tujuan dari penelitian ini yaitu untuk memberikan informasi mengenai UMKM di Kabupaten Blitar. Hasil dari penelitian ini adalah webgis menggunakan google maps api sebagai peta dasar. Dengan data spasial berupa koordinat lokasi, alamat dan data non spasial berupa data dan informasi pendukung berupa nama UMKM, kategori, jenis produk, alamat, kontak atau nomor telefon, pemilik atau penanggung jawab, dan foto UMKM. Serta dilengkapi dengan fitur pencarian dan menambah informasi UMKM [14].

\section{METODE PENELITIAN}

Metode penelitian sangat diperlukan untuk kesempurnaan sistem yang penulis akan buat. Diperlukan metode-metode penelitian agar diperoleh data yang tepat dan akurat. 


\subsection{Sumber data}

1. Data Primer adalah data mengenai informasi lokasi home industry, gambaran home industry, informasi mengenai jumlah produksi, jumlah pekerja, dan omset setiap bulannya.

2. Metode Observasi ,terlibat langsung dalam melakukan penelitian diinstansi terkait yaitu Dinas UMKM dan Koperasi Kabupaten Wonogiri dan Kecamatan Girimarto untuk memperolah data home industry yang ada di Kecamatan Girimarto.

3. Metode Wawancara untuk mendapatkan data jumlah produksi, jumlah pekerja, jumlah omset, dan produk yang dihasilkan.

4. Data Sekunder, sumber-sumber yang telah mengandung data lokasi dan data buku, yang dapat digunakan sebagai bahan laporan.

\subsection{Metode Pengembangan Sistem}

Didalam metode pengembangan sistem terdapat perancangan sistem sebagai berikut:

\subsubsection{Use Case Diagram}

Use case diagram pemetaan potensi wilayah home industry di Kecamatan Girimarto dengan fuzzy tahani menggambarkan Interaksi pengguna (user) dan admin terhadap sistem. User dapat melihat data home industry, peta persebaran dan juga mencari data sesuai kriteria yang diinginkan. Sedangkan admin dapat melakukan manipulasi terhadap data home industry seperti tambah data, edit dan hapus.

\subsubsection{Class Diagram}

Class terdiri dari nama kelas, atribut dan method dalam aplikasi pemetaan home industry di Kecamatan Girimarto

\subsubsection{Activity Diagram}

Activity diagram menggambarkan alur aktivitas admin terhadap sistem. Ada beberapa activity diagram yang terdapat pada aplikasi pemetaan potensi wilayah home industry di Kecamatan Girimarto dengan metode fuzzy tahani antara lain activity diagram melakukan login, menginput data, mengedit data, menghapus data dan melakukan logout.

\subsubsection{Sequence Diagram}

Menggambarkan interaksi antar objek didalam dan disekitar sistem (pengguna dan tampilan). Beberapa sequence diagram yang ada di aplikasi pemetaan potensi wilayah home industry di Kecamatan Girimarto dengan fuzzy tahani diantaranya menginput data home industry, menampilkan data home industry, mengedit data, menghapus data, dan proses perhitungan dengan fuzzy tahani.

\subsection{Pengujian Sistem}

1. Pengujian BlackBox

Untuk dapat mengetahui apakah aplikasi dapat berjalan sesuai dengan fungsi yang telah dibuat.

\section{Uji Kelayakan}

Untuk mendapatkan penilaian langsung dari respon terhadap sistem yang dihasilkan. Pengujian akan dilakukan dengan menyebarkan angket kepada pemilik home industry dan masyarakat. Angket analisa kelayakan aplikasi diolah dengan menggunakan skala Likert dengan rentang skala 1 sampai 5 . Dengan presentase kelayakan aplikasi seperti yang dapat dilihat pada Tabel 1.

Tabel 1. Skala Kelayakan

\begin{tabular}{|c|l|}
\hline Presentase & \multicolumn{1}{|c|}{ Kategori } \\
\hline $0 \%-20 \%$ & Sangat Kurang Layak \\
\hline $21 \%-40 \%$ & Kurang Layak \\
\hline $41 \%-60 \%$ & Cukup Layak \\
\hline $61 \%-80 \%$ & Layak \\
\hline $81 \%-100 \%$ & Sangat Layak \\
\hline
\end{tabular}

\section{HASIL DAN PEMBAHASAN}

\subsection{Penerapan Fuzzy Tahani}

Dalam tahap ini akan dijelaskan langkahlangkah pengoperasian algoritma fuzzy tahani secara manual. Berikut ini data industri yang akan diolah dengan menggunakan metode fuzzy tahani, dapat dilihat pada Tabel 2.

Tabel 2 Tabel Data

\begin{tabular}{|c|c|c|c|c|}
\hline No & Nama & $\begin{array}{c}\text { Kapasitas } \\
\text { Produksi } \\
\text { /Tahun }\end{array}$ & $\begin{array}{c}\text { Tenaga } \\
\text { Kerja }\end{array}$ & $\begin{array}{c}\text { Omset } \\
\text { /Tahun } \\
\text { (Rp.000) }\end{array}$ \\
\hline 1 & Industri 1 & $1200 \mathrm{~kg}$ & 4 org & 96.000 \\
\hline 2 & Industri 2 & $3600 \mathrm{~kg}$ & 4 org & 360.000 \\
\hline 3 & Industri 3 & $1800 \mathrm{~kg}$ & 2 org & 198.000 \\
\hline 4 & Industri 4 & $6000 \mathrm{~kg}$ & 2 org & 720.000 \\
\hline 5 & Industri 5 & $3600 \mathrm{~kg}$ & 3 org & 306.000 \\
\hline 6 & Industri 6 & $10800 \mathrm{~kg}$ & 6 org & 1.080 .000 \\
\hline 7 & Industri 7 & $14400 \mathrm{~kg}$ & 6 org & 1.314 .000 \\
\hline
\end{tabular}

1. Melakukan Fuzzifikasi untuk mencari nilai keanggotan setiap data berdasarkan variabelnya.

a. Fuzzifikasi variabel produksi

Perhitungan fuzzifikasi variabel produksi menggunakan rumus (1),(2),(3) berdasarkan data jumlah produksi

- Industri 1

Kapasitas Produksi: 1200

$\mu$ KPsedikit : 1

- Industri 2

Kapasitas Produksi: 3600

$\mu \mathrm{KPsedang} \quad: \frac{3600-3000}{4500-1000}=\frac{600}{1500}=0,4$ 
- Industri 3

Kapasitas Produksi: 1800

$\mu$ KPsedikit

$$
\frac{\frac{5}{3500-1800}}{3500-1200}=\frac{700}{2300}=
$$

- Industri 4

Kapasitas Produksi: 500

$\mu$ KPtinggi

$$
\frac{6000-5000}{12000-5000}=\frac{1000}{7000}=0,14
$$

- Industri 5

Kapasitas Produksi: 3600

HKPsedikit $\quad: \frac{3600-15500}{4500-9500}=\frac{600}{1000}=0,6$

- Industri 6

Kapasitas Produksi: 10800

$\mu$ KPbanyak

$$
\begin{aligned}
& \frac{10800-5000}{12000-5000}=\frac{5800}{7000}= \\
& 0,83
\end{aligned}
$$

- $\quad$ Industri 7

Kapasitas Produksi :14400

$\mu \mathrm{KPbanyak}$

$: 1$

Tabel 3 Hasil fuzzifikasi Produksi

\begin{tabular}{|l|l|c|c|c|}
\hline \multirow{2}{*}{ No } & \multirow{2}{*}{ Nama } & \multicolumn{3}{|c|}{ Derajat Keanggotaan Produksi } \\
\cline { 3 - 5 } & & $\begin{array}{c}\text { KP } \\
\text { sedikit }\end{array}$ & $\begin{array}{c}\text { KP } \\
\text { sedang }\end{array}$ & $\begin{array}{c}\text { KP } \\
\text { banyak }\end{array}$ \\
\hline 1 & Industri 1 & 1 & 0 & 0 \\
\hline 2 & Industri 2 & 0 & 0.4 & 0 \\
\hline 3 & Industri 3 & 0.3 & 0 & 0 \\
\hline 4 & Industri 4 & 0 & 0 & 0.14 \\
\hline 5 & Industri 5 & 0 & 0.6 & 0 \\
\hline 6 & Industri 6 & 0 & 0 & 0.83 \\
\hline 7 & Industri 7 & 0 & 0 & 1 \\
\hline
\end{tabular}

b. Fuzzifikasi variabel tenaga kerja

Perhitungan fuzzifikasi variabel tenaga kerja menggunakan rumus (3), (4), (5) berdasarkan data jumlah pekerja.

- Industri 1

$$
\begin{array}{ll}
\text { Tenaga Kerja } & : 4 \\
\mu \text { TKsedang } & : \frac{4-3}{4-3}=\frac{1}{1}=1
\end{array}
$$

- Industri 2

Tenaga Kerja

$: 4$

$\mu$ TKsedang

$: \frac{4-3}{4-3}=\frac{1}{1}=1$

- Industri 3

Tenaga Kerja : :2

$\mu$ TKsedikit $\quad: 1$

- Industri 4

Tenaga Kerja : : 2

$\mu$ TKsedikit $\quad: 1$

- Industri 5

Tenaga Kerja $\mu$ TKsedikit $\quad: \frac{4-3}{4-2}=\frac{1}{2}=0,5$

- Industri 6

Tenaga Kerja : :6

$\mu$ TKbanyak $: 1$

- Industri 7

Tenaga Kerja : :6

$\mu$ TKbanyak $: 1$

Tabel 4 Hasil Fuzzifikasi Tenaga Kerja

\begin{tabular}{|l|c|c|c|c|}
\hline \multirow{2}{*}{ No } & \multirow{2}{*}{ Nama } & \multicolumn{3}{|c|}{ Derajat Keanggotaan Tenaga } \\
\cline { 3 - 5 } & & $\begin{array}{c}\text { TK } \\
\text { sedikit }\end{array}$ & $\begin{array}{c}\text { TK } \\
\text { sedang }\end{array}$ & $\begin{array}{c}\text { TK } \\
\text { banyak }\end{array}$ \\
\hline 1 & Industri 1 & 0 & 1 & 0 \\
\hline 2 & Industri 2 & 0 & 1 & 0 \\
\hline 3 & Industri 3 & 1 & 0 & 0 \\
\hline 4 & Industri 4 & 1 & 0 & 0 \\
\hline 5 & Industri 5 & 0.5 & 0 & 0 \\
\hline 6 & Industri 6 & 0 & 0 & 1 \\
\hline 7 & Industri 7 & 0 & 0 & 1 \\
\hline
\end{tabular}

c. Fuzzifikasi variabel omset

Perhitungan fuzzifikasi variabel omset menggunakan rumus (7), (8), berdasarkan data jumlah omset.

- Industri 1

Omset

: 96.000 .000

$\mu$ OTrendah

$: 1$

- Industri 2

Omset

OOTsedang

: 360.000 .000

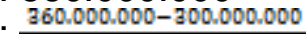

1.400,000,000-300,000000

$=\frac{60.000 .000}{1.100 .000 .000}=0.054$

- Industri 3

Omset

: 198.000 .000

OOTrendah

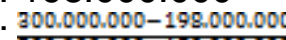

: $3000000000-150000000$

- Industri 4

$$
=\frac{102.000 .000}{150,000.000}=0.68
$$

Omset

$\mu$ OTsedang

720.000 .000

$720.000000-900,000000$

1400,000,000-900,000000

$=\frac{420.000 .000}{1.100 .000 .000}=0.38$

- Industri 5

Omset

$\mu$ OTMrendah

: 360.000 .000

a06.0001000-a00,000.000

1400,000000-300,000000

$=\frac{6000.000}{1.100 .000 .000}=0.054$

- Industri 6

Omset

: 1.080 .000 .000

$\mu$ OTsedang

: 1.080000000-a00000000

$=\frac{720.000000}{1.100000000}=0.71$

- $\quad$ Industri 7

Omset

: 1.314 .000 .000

$\mu$ OTsedang

$1.400,000,000-900,000000$

$=\frac{1.014 .000 .000}{1.100 .000 .000}=0.92$ 
Tabel 5 Hasil Fuzzifikasi Omset

\begin{tabular}{|l|l|c|c|c|}
\hline \multirow{2}{*}{ No } & \multirow{2}{*}{ Nama } & \multicolumn{3}{|c|}{ Derajat Keanggotaan Omset } \\
\cline { 3 - 5 } & & OT rendah & OT sedang & OT tinggi \\
\hline 1 & Industri 1 & 1 & 0 & 0 \\
\hline 2 & Industri 2 & 0 & 0.054 & 0 \\
\hline 3 & Industri 3 & 0.68 & 0 & 0 \\
\hline 4 & Industri 4 & 0 & 0.38 & 0 \\
\hline 5 & Industri 5 & 0 & 0.054 & 0 \\
\hline 6 & Industri 6 & 0 & 0.71 & 0 \\
\hline 7 & Industri 7 & 0 & 0.92 & 0 \\
\hline
\end{tabular}

\subsection{Implementasi sistem}

Hasil dari penerapan metode fuzzy tahani dalam sistem ini seperti yang dapat dilihat pada Gambar 4.

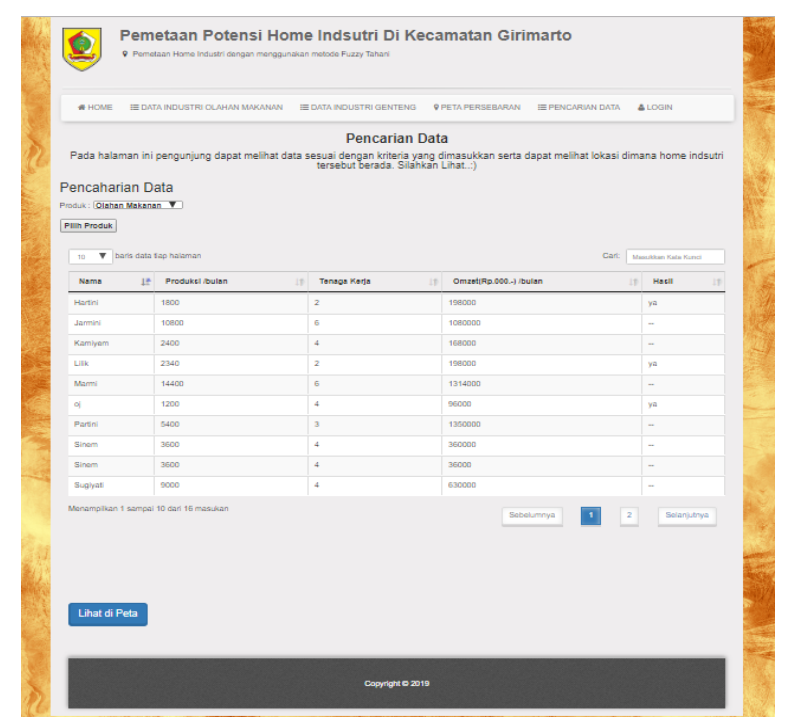

Gambar 4. Pencarian dengan fuzzy Tahani

Setelah itu jika meng-klik tombol lihat peta maka akan diarahkan ke halaman peta sehingga bisa melihat lokasi home industry. Di halaman ini akan menampilkan hasil data sesuai dengan kriteia yang telah dipilih dengan tanda marker berwarna hijau, sedangkan marker yang berwarna kuning bukan hasil dari kriteia yang telah ditentukan seperti yang dapat dilihat pada Gambar 5.

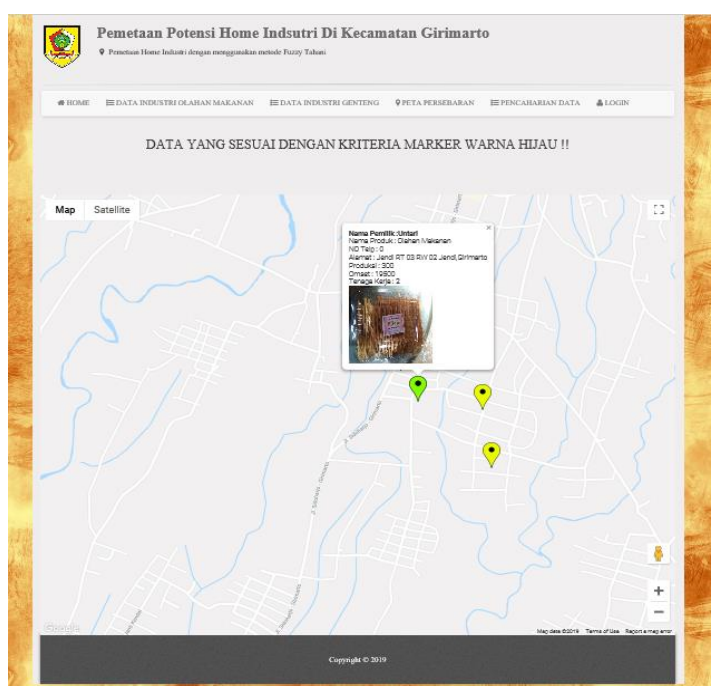

Gambar 5 Hasil Pencarian

\subsection{Pengujian Sistem}

\subsubsection{Pengujian Fungional}

Pengujian fungsionalitas dengan menggunakan blackbox mendapatkan hasil bahwa semua komponen - komponen yang terdapat dalam aplikasi pemetaan home industry dapat digunakan dan difungsikan sesuai dengan tujuannya.

\subsubsection{Uji Kelayakan}

Pengujian dengan menyebarkan angket kepada pemilik home industry dan juga pengguna dengan jumlah responden sebanyak 30 orang dengan hasil penerimaan user/pengguna terhadap aplikasi yang dibuat sebesar 75,167\%. Berdasarkan tabel 1 dengan presentase perolehan menunjukkan bahwa aplikasi layak digunakan.

\section{PENUTUP}

\subsection{Kesimpulan}

Kesimpulan yang dapat diambil dari pembuatan sistem ini adalah sebagai berikut :

1. Terbangunnya sistem pemetaan potensi wilayah home industry di Kecamatan Girimarto Kabupaten Wonogiri dengan menggunakan metode fuzzy tahani. Dengan variabel jumlah produksi per tahun, jumlah tenaga kerja, dan jumlah omset per tahun. Terdapat tiga kriteria dari setiap variabel yang digunakan dalam sistem ini diantaranya yaitu sedikit, sedang banyak. Sistem yang tersebut menghasilkan informasi data industri sesuai dengan kriteria yang ditentukan dengan nilai fire strength tertinggi 1.

2. Sistem hanya akan menampilkan hasil klasifikasi dari semua variabel berdasarkan kriteria yang dipilih, sistem belum dapat 
menampilkan hasil klasifikasi dari satu variabel,

3. Aplikasi yang dibangun sudah layak digunakan. Hal ini didapat dari hasil uji kelayakan dengan jumlah responden sebanyak 30 orang dengan presentase penerimaan sebesar $75,167 \%$ yang dapat dinyatakan bahwa aplikasi dapat berjalan dengan baik dan layak digunakan.

\subsection{Saran}

Saran yang dapat diberikan guna pengembangan sistem adalah sistem yang dibuat masih sederhana, akan lebih baik lagi jika ditambahkan menu atau fitur promosi untuk pengunjung umum, sehingga pengguna/masyarakat umum dapat melihat detail produk yang dijual dan juga pelaku home industry diberikan akses untuk dapat memperbarui data produk mereka masingmasing.

\section{DAFTAR PUSTAKA}

[1] A. P. Astari and R. Komarudin, "Sistem Pendukung Keputusan Pemilihan Karyawan Terbaik Dengan Metode Fuzzy Tahani," J. Penelit. IImu Komputer, Syst. Embed. Log., 2018.

[2] I. Ewi, "Implementasi Fuzzy Database Model Tahani untuk Pembelian Rumah Perumnas," Semin. Nas. Teknol. Inform. Komun. dan Ind. 9, 2017.

[3] K. Soraya, H. Kurniawan, and F. Tahel, "Perancangan Aplikasi Pengukuran Kualitas Spring Bed Pada PT. Cahaya Bintang Selatan Menggunakan Metode Fuzzy Tahani," Konf. Nas. Sist. Inf. 2018, 2018.

[4] A. ulfa Laelasari, "Penerapan Metode Clustering Means (C-Means) Dan Fuzzy Tahani Pada Sistem Informasi Hewan Ternak Sapi Berkualitas Berbasis Website (Studi Kasus: Dinas Peternakan Dan Perikanan Kabupaten Semarang)," Skripsi Univ. Negeri Semarang, 2016.

[5] G. Taufiq, "Logika Fuzzy Tahani Untuk Pendukung Keputusan Perekrutan Karyawan Tetap," Pros. Semin. Nas. Apl. Sains Teknol. 2014, 2014.

[6] P. Eddy, Sistem Informasi Geografis: Konsep-Konsep Dasar. Bandung: Informatika, 2014.

[7] N. Rizkika, "Pengembangan Usaha Home Industri Air Kerawang Perspektif Ekonomi Islam," Skripsi IAIN Raden Intan Lampung, 2017.
[8] S. Kusumadewi and H. Purnomo, Aplikasi Logika Fuzzy Untuk Pendukung Keputusan. Yogyakarta: Graha IImu, 2004.

[9] S. Kusumadewi, Aplikasi Logika Fuzzy Untuk Pendukung Keputusan. Yogyakarta: Graha IImu, 2013.

[10] S. Kusumadewi, Konsep Aplikasi dan Sistem Pendukung Keputusan. Yogyakarta: Graha IImu, 2014.

[11] D. E. S. Purnomo, "Sistem Pendukung Keputusan Untuk Pemilihan Obyek Wisata Di Surakarta Menggunakan Metode Fuzzy Tahani," Tugas Akhir Univ. STIKUBANK, 2013.

[12] M. H. Sururi, "Penggunaan Fuzzy Tahani Untuk Sistem Informasi Stok Obat \& Penjualan Obat Terlaris Pada Apotek RSU Lirboyo Kediri," Artik. Skripsi Univ. Nusant. PGRI Kediri, 2015.

[13] B. A. Abdullah, "Sistem Informasi Geografis Sebaran Umkm Di Kota Cimahi," Semin. Nas. Teknol. Inf. dan Multimed., 2018.

[14] A. Fadhila and A. Budi, "Pembuatan Webgis Untuk Pemetaan Usaha Mikro Kecil Menengah (UMKM) Di Kabupaten Blitar," J. Tek. ITS, vol. Vol. 6 No., 2017. 